\title{
INFLUENCE OF IODINATED OIL AND MARGARINE ON THE THYROID SYSTEM OF RATS
}

\author{
Rodica A. Sturza ${ }^{a}$, Olga I. Deseatnicova, Cristina M. Popovici* ${ }^{a}$, Valentin S. Gudumac ${ }^{\mathrm{b}}$, Ion \\ Nastas $^{b}$ \\ ${ }^{a}$ Technical University of Moldova, 168 Stefan cel Mare bldv., MD 2004 Chisinau, Moldova, tel.: 23-86-45, fax: 31 - 91 - 76 , \\ E-mail : cristina_popovici@mail.md \\ ${ }^{b}$ State Medical and Pharmaceutical University “Nicolae Testemitanu”, Moldova
}

\begin{abstract}
Iodine deficiency is the most prevalent micronutrient deficiency in the world today. Food fortification is an important compliment to food-based approaches, and iodine fortification of foods as one of the strategies for the control of iodine deficiency. Manufacturing and consumption of sunflower oil fortified with iodine as well as derivative products on it basis is a perspective direction for elimination of alimentary dependent iodine deficiency disorders. The present work examines morphological changes in the thyroid system of rats at the experimental mercatholile-induced hypothyroidism. As well it determines the influence of iodinated oil and margarine on the thyroid system of rats. It specifies the safe value of iodinated oil and margarine for rats. In-vivo study demonstrated the efficacy of fortification of lipid products with iodine under iodine deficiency status.
\end{abstract}

Key words: Iodine deficiency, food fortification, sunflower oil, margarine, in vivo study.

\section{Introduction}

The problem of iodine deficiency (ID) is one of the main problems of the world society, including Republic Moldova [1]. ID affects all population at all stages of life, from the intrauterine stage to old age [2,3].

The environment of Republic Moldova is characterized by a reduced values of the iodine content: $4,5-5,3 \mathrm{mg} / \mathrm{kg}$ soil, $40 \mathrm{mg} / \mathrm{l}$ water and $0,03-0,22 \mathrm{mg} / \mathrm{kg}$ of vegetation, on a dry content of substances. Approximate $85 \%$ of populations of Moldova live in iodine deficient regions [4]

Researches performed by WHO and UNICEF in the Republic of Moldova have demonstrated a 37\% prevalence of endemic goiter among children and teenagers [ 5].

In order to eliminate the iodine deficiency disorders, the Government Decision nr. 585 "Decision regarding the approving of national system of eradication of disorders caused by iodine deficit till the 2010" was approved on 1 June 2007 as a way of addressing the problem of iodine deficiency disorders and was adopted as Law. It provides instructions for the fortification of foodstuffs with nutrients that have insufficient values in local region [6].

The most appropriate way of fighting the iodine deficiency is to produce foodstuff for functional purposes which contain stable forms of iodine [7].

Sunflower oil takes up the biggest specific weight among edible fats used in nutrition in the Republic Moldova. Iodine administration in products with a lipid origine represents a remarkable interest. First, this would allow the easy incorporation of the iodine in the food fatty products. Secondly, the daily intake of lipids being limited, would alow an easy regulation of the iodine consumption, this being complementary with that from the iodinated salt and other products

The aim of the research consisted of examination of metabolic displacement in the organism of animals and correction of experimental and spontaneous thyroid pathology by means of iodinated food products (sunflower oil, margarine).

\section{Results and discussion}

The level of thyroid hormones of rats during the examination of iodinated sunflower oil and margarine.

For getting of the model of artificial hypothyroidism mercazolile was used for blocking the thyroid gland function. Peroxidase catalyzes the oxidation reactions. It is known that the activity of oxidation ferments decreases on hypothyroidism and increases on hyperthyroid states [8].

Mercazolile depresses the ferment activity of iodineperoxidase - the ferment which provides the iodination of $\alpha$ - thyroxine. It provokes hypothyroidism because iodine an obligatory ingredient of thyroxine. [9]

Biological activity of examined iodinated products was evaluated according to indexes that reflect the functional state of animals' thyroid gland. Pursuing this aim, the level of thyroid gland hormones such as total Triiodothyronine $\left(\mathrm{T}_{3}\right)$, Thyroxine $\left(\mathrm{T}_{4}\right)$ in the experimental rats' blood serum was determined. The condition of the hypophysial-thyroid system was evaluated according to the content of serum Thryroid-stimulating hormone (TSH, Thyrotropin). [10-13]. Received data reflected in the Table 1. 
Content of thyroid hormones in the rats' serum.

\begin{tabular}{|c|c|c|c|}
\hline \multirow{2}{*}{ Group of rats } & $\begin{array}{c}\text { Total Triiodothyronine } \\
\text { hormone }\left(\mathrm{T}_{3}\right)\end{array}$ & Thyroxine hormone $\left(\mathrm{T}_{4}\right)$ & $\begin{array}{c}\text { Thyroid-stimulating } \\
\text { hormone (TSH, } \\
\text { thyrotropin) }\end{array}$ \\
\cline { 2 - 4 } & $\mathrm{ng} / \mathrm{dl}$ & $\mathrm{nmol} / \mathrm{l}$ & $\mathrm{muI} / \mathrm{l}$ \\
\hline I & $92,65 \pm 19,12$ & $114.1 \pm 16.49$ & $0.894 \pm 0.032$ \\
\hline II & $84,65 \pm 14,54$ & $93.1 \pm 14.54$ & $0.966 \pm 0.025$ \\
\hline III & $89,94 \pm 18,52$ & $95.81 \pm 19.53$ & $0.856 \pm 0.099$ \\
\hline IV & $90,26 \pm 13,39$ & $107.42 \pm 15.02$ & $0.814 \pm 0.034$ \\
\hline V & $91,15 \pm 16,76$ & $119.37 \pm 14.43$ & $1,257 \pm 0.027$ \\
\hline VI & $73,00 \pm 19,94$ & $92.83 \pm 14.48$ & \\
\hline
\end{tabular}

Data regarding blood serum immune-enzyme analysis witnesses the decrease of thyroid gland functional activity in rats that were in the condition of experimental hypothyroidism (II and III group). Introduction of mercasolile called experimental hypothyroidism condition that was accompanied by morphological functional displacement in the thyroid system, expressed in $\mathrm{T}_{4}$ level decrease and TSH concentration increase in the controlled group (group I) (Figure 1).
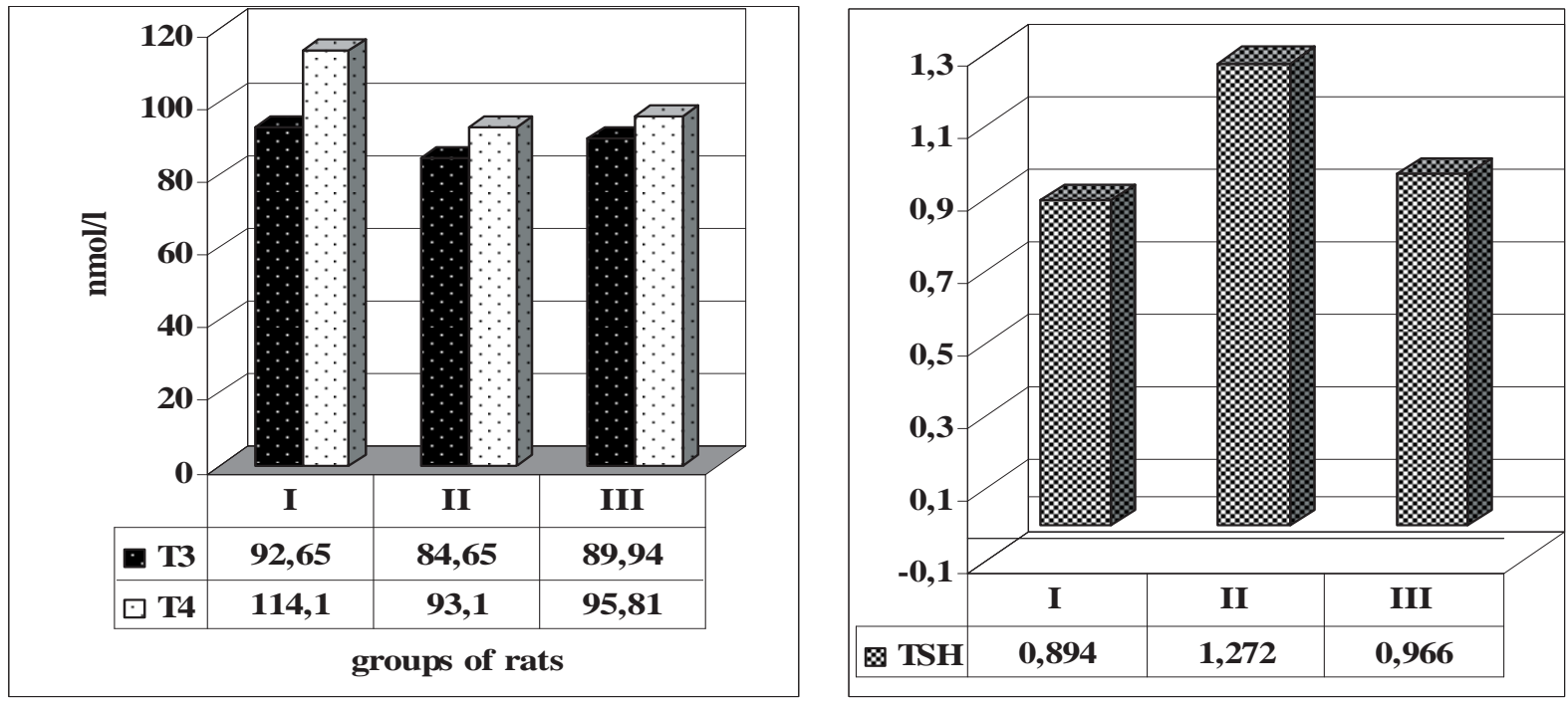

Fig 1. Content of thyroid harmonious in the serum of rats belonging to I, II, III groups.

Thus, $\mathrm{T}_{4}$ concentration in the hypothyroid rats serum (IInd group) decreased and become $93.1 \pm 14.54 \mathrm{nmol} / 1$, in the IIIrd group $-95,81 \pm 19.53 \mathrm{nmol} / 1$ against $114.1 \pm 16.49 \mathrm{nmol} / 1$ of the controlled group. At the same time hypothyroidism contributes to the increase of thyrotrophic hormone (TSH) with $0.894 \pm 0.032$ mul/1 (controlled group) till $1.272 \pm 0.037 \mathrm{mul} / 1$ (IInd group) and $0.966 \pm 0.025 \mathrm{mul} / \mathrm{l}$ (IIIrd group).

Thereby, experimental rats, introduced in the condition of mercasolile hypothyroidism, show expressed destructive-degenerative processes in the thyroid glands in comparison with the control group. In the thyroid grand the lack of colloid in follicles is the result of termination of thyreoglobulin thyrocotis synthesis.

All thyroxine (T4) and some triiodothyronine (T3) are produced by the thyroid gland, and their production there is stimulated by thyroid-stimulating hormone (TSH, thyrotropin), a product of the anterior pituitary gland. Some T4 is converted to T3 in other tissues, including the pituitary gland and the hypothalamus. T3 inhibits pituitary secretion of TSH, and hypothalamic secretion of thyrotropin-releasing hormone (TRH), which stimulates TSH secretion. The interplay between T3 and TSH maintains thyroid hormone production within a narrow range. 


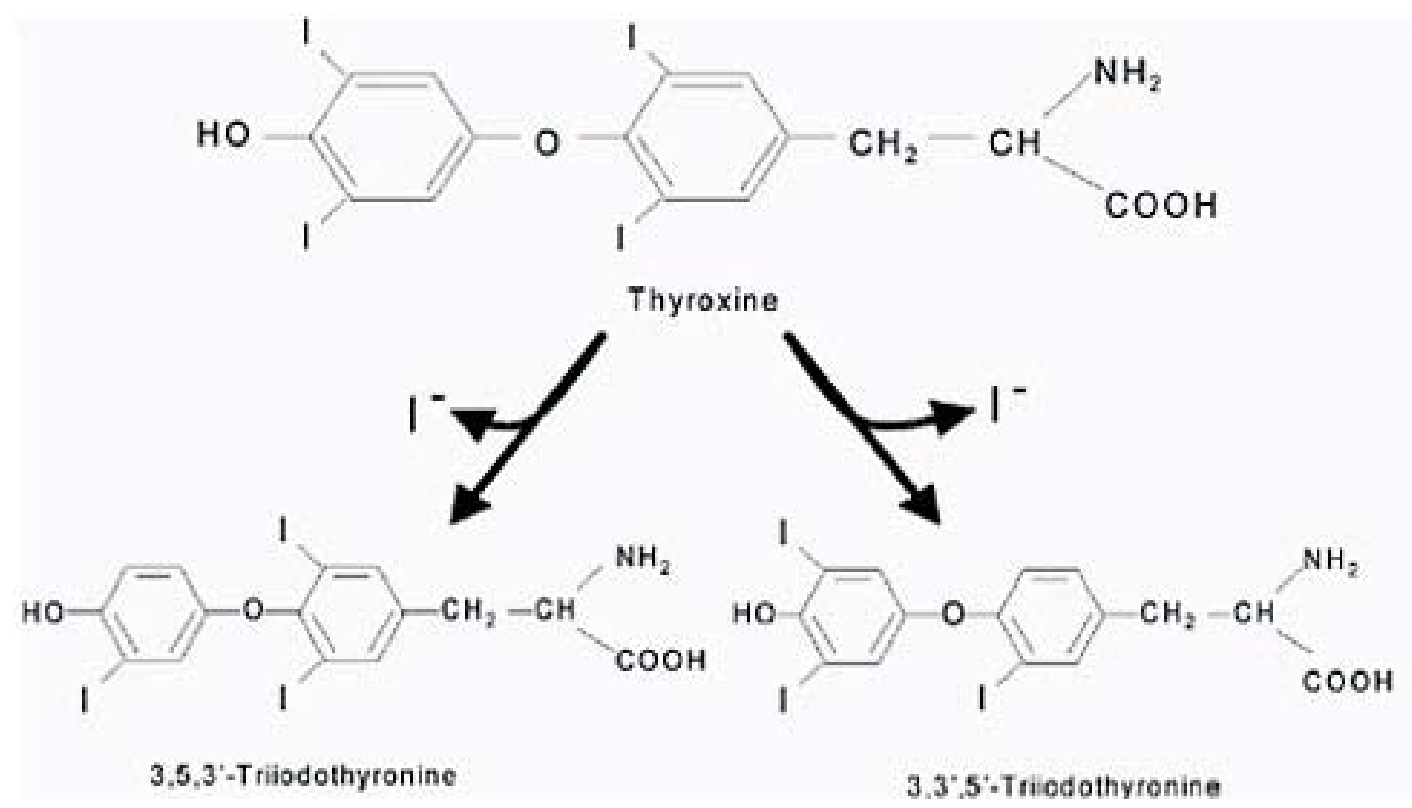

It is necessary to note, that the $\mathrm{T}_{3}$ concentration at the hypothyroid rats (IInd and IIIrd group) did not decrease significantly; that can be explained as activation of deiodination $\mathrm{T}_{3}$ in $\mathrm{T}_{4}$ processes:

The present regularity is observed as the account of protective-compensatory animal reaction in the condition of iodination blocking of remaining tyrosine as a component of thyreoglobulin.

In the course of further research the evaluation of efficacy and safety of examined iodine complexes was performed in the five groups.

The analysis of the received data confirms that organically connected forms of iodine contributed to the increase of functional activity of thyroid gland. Thus, rats of IVth and Vth groups had significantly higher serum $\mathrm{T}_{4}$ level then animals of IInd and IIIrd group (Figure 2).
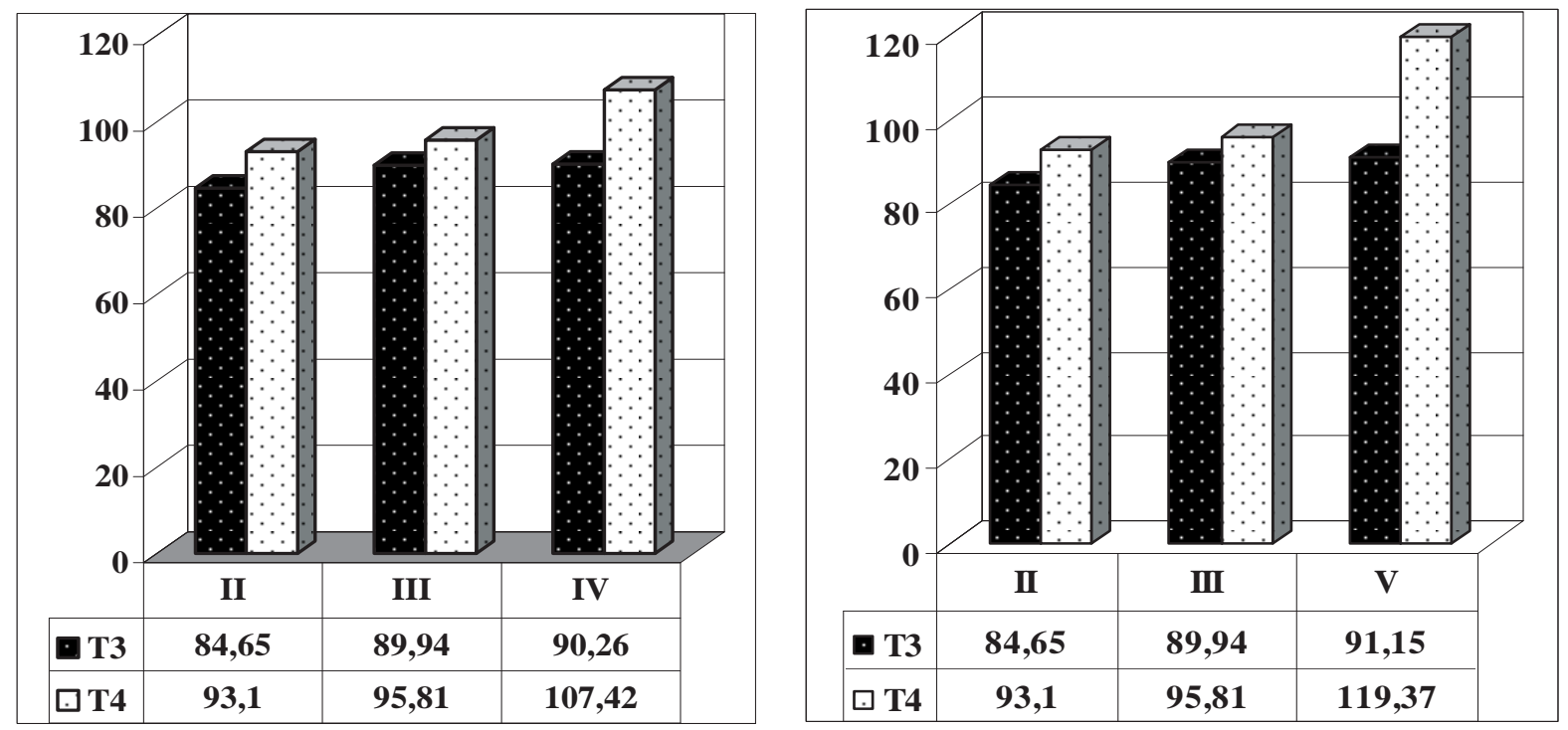

Fig 2. Content of thyroid harmonious in the serum of rats belonging to II, III, IV и V groups.

At the same time $\mathrm{T}_{4}$ concentration in the IVth group made up 107-42 $\pm 15-02 \mathrm{nmol} / \mathrm{l}$, in the Vth one 119-37 \pm 14.43 $\mathrm{nmol} / \mathrm{l}$ against $93.1 \pm 14.54 \mathrm{nmol} / 1$ in the IInd one and $95.81 \pm 19.53 \mathrm{nmol} / 1$ in the IIIrd one. Concentration of $\mathrm{T}_{3}$ in the compared groups does not differ in a significant way, remaining in limits of 90,26 $\pm 13,39 \mathrm{ng} / \mathrm{dl}$ (IVth group) and $91,15 \pm 16,76 \mathrm{ng} / \mathrm{dl}$ (Vth group). The relatively high level of $\mathrm{T}_{3}$ of the IIIrd group rats $(98,94 \pm 18,52 \mathrm{ng} / \mathrm{dl})$ is explained by the activation of $\mathrm{T}_{4}$ deiodation processes in the condition of iodine deficit.

All animals who received additionally daily iodinated sunflower oil and margarine, showed increased level of $\mathrm{T}_{4}$ secretion accompanied by rather low TSH level (Figure 3). 


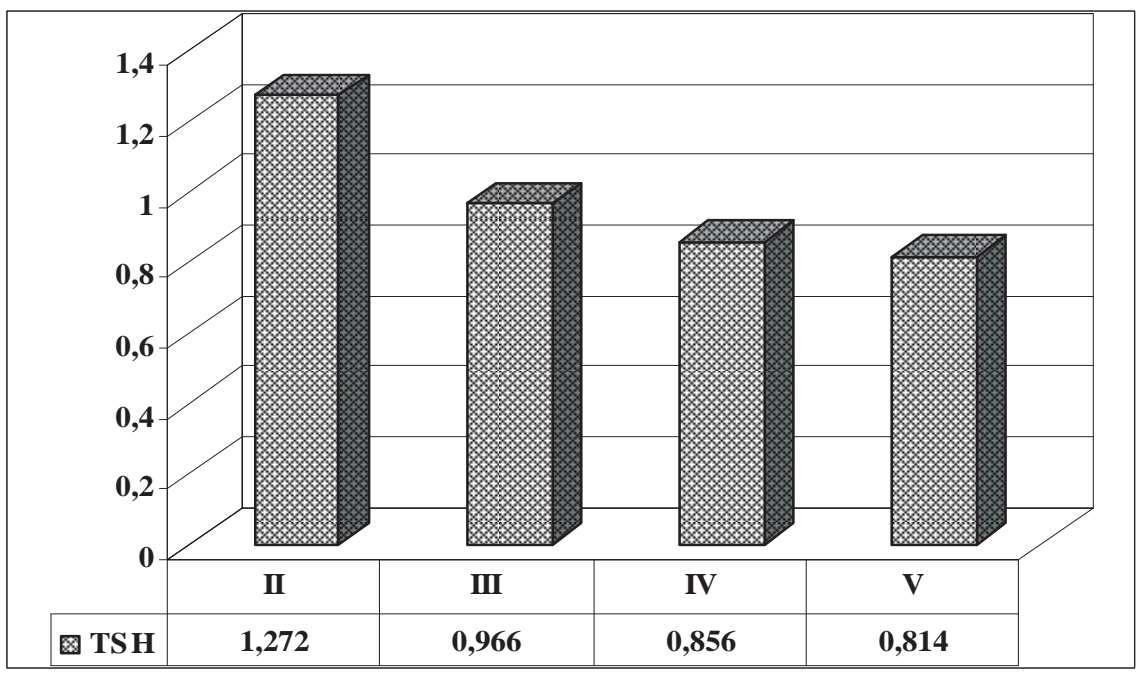

Fig 3. Influence of iodinated food products over the rat thyroid-stimulating hormone synthesis.

Hereby, if animals of the IInd and IIIrd group have TSH concentration of 1.272 $\pm 0 / 037 \mathrm{muI} / 1$ and 0/966 \pm 0.025 $\mathrm{muI} / 1$ correspondingly, in rats of the IVth and Vth groups identical indexes reflected 0/856 $\pm 0,099 \mathrm{muI} / 1$ and $0.814 \pm 0 / 034$ $\mathrm{muI} / \mathrm{l}$. It is the evidence of stimulating influence of examining iodine products over the functional activity of rats' thyroid glands. Received data match with the research results reported by Kashin, Egorov, Fencenco, Gusakov [ 14-17].

Use of iodine sunflower oil and margarine in the rats' ration contributed to the gradual restoration of tyrocyte functional activity with the formation of colloid in follicles. All tested iodinated products have the homogeneous actions in the view of tyrocytes activity restoration.

When the main components of the tyroglobuline-iodine in the combination with fatty acids enter the organism, the synthesis of thyroid hormones in tyrocytes restarts. Consequently, regeneration possibilities and differentiation of thyroid glands tyrocytes are high and used substances assist in it. Positive activity of iodine products for the animals' organism are marked in the works of $[14,18]$.

Besides of that we carried out the research in evaluation of iodinated sunflower oil safety that included examination of chronic toxicity as well. The toxicity was tested on the animals (of IVth group) that received daily during the whole experiment period 10 -fold iodine dose.

The value of tested iodine dose efficiency and safety over the rat organism held in two compared groups: IV - introduction of 1-fold iodine dose in iodine sunflower oil and VI group. The analysed data show that tested organic connected iodine form is not toxic for the experimental animals. Thus, the rats of VI group had the following $\mathrm{T}_{3}$ and $\mathrm{T}_{4}$ concentration level $73,00 \pm 19.94 \mathrm{ng} / \mathrm{dl}$ and $92,83 \pm 14.48 \mathrm{nmol} / \mathrm{l}$ against $90.26 \pm 13.39 \mathrm{ng} / \mathrm{dl}$ and $107.42 \pm 15.02 \mathrm{nmol} / \mathrm{l}$ in the IV group correspondingly. Meantime the TSH level of the rats from the VIth group increased and constituted $1.257 \pm 0.027 \mathrm{muI} / 1$ in comparison with TSH concentration of rats from IV group $-0.856 \pm 0 / 099 \mathrm{muI} / \mathrm{l}$ (Figure 4).
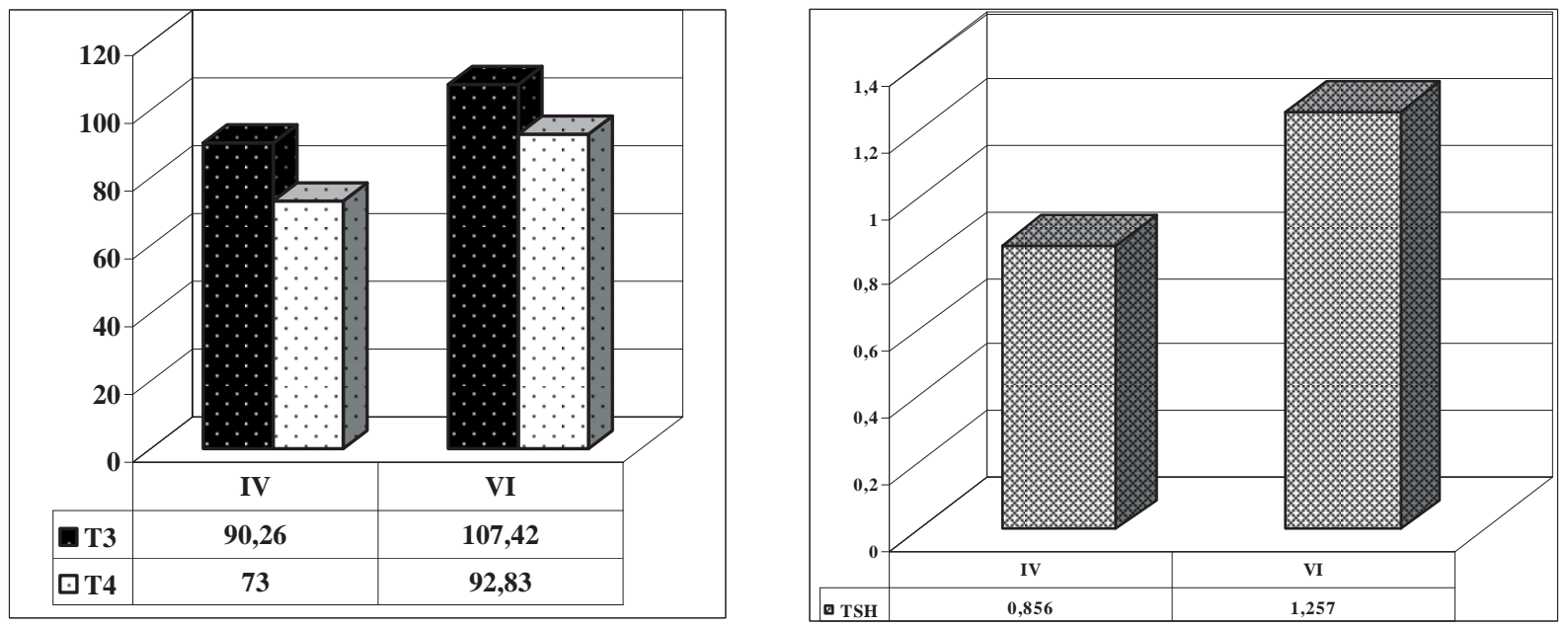

Fig 4. Influence of 10-fold iodine dose in the structure of iodinated food products over the synthesis of rat thyroid hormones 
Data received in the result of our research certify that the consumption of iodine in large quantities leads to decrease of $\mathrm{T}_{3}$ and $\mathrm{T}_{4}$ hormone secretion and increase of TSH concentration in comparison with the group of rats that received 1-fold iodine dose. It can be explained by decrease of thyroid gland ability to accumulate iodine and large quantities of iodine removed from the organism through kidneys.

It is necessary to mark, that iodinated sunflower oil and margarine contributed to better use of feedstuff for rats. Received data coincide with the messages of Alioshin, Bataev, Georgievskii [8, 19, 20].

Effect of iodine intake on iodine content of thyroid gland.

Iodine content in thyroid glands characterizes the intensity and direction of iodine metabolism of animals. Our investigations on iodine accumulation in thyroid glands confirmed the positive influence of optimal iodine level ( $3 \mu \mathrm{g} /$ rat) on organism of experimental animals. Our data on investigation of iodine content in thyroid glands agree with the works of Baranov and Seleatitskaia [10,21].

Feeding of experimental animals with optimal iodine level $(3 \mu \mathrm{g} / \mathrm{rat})$ increased the functional activity of thyroid gland and iodine concentration in it (table 2). The obtained data are congruent with the investigation results of Fenchenco and Kashin $[16,14]$.

Table 2

Effect of iodine intake on iodine content of thyroid gland

\begin{tabular}{|c|c|c|c|}
\hline \multirow{2}{*}{ Group of rats } & $\begin{array}{c}\text { Iodine content of } \\
\text { diet }\end{array}$ & $\begin{array}{c}\text { Weight of thyroid } \\
\text { gland }\end{array}$ & Thyroid iodine \\
\cline { 2 - 4 } & $\mu \mathrm{g} / \mathrm{rat}$ & $\mathrm{mg}$ & $\mathrm{mg} \%$ \\
\hline I & $0,4 \pm 0,1$ & $25,8 \pm 1,5$ & $4,8 \pm 0,9$ \\
\hline II & $0,4 \pm 0,1$ & $34,2 \pm 1,7$ & $1,2 \pm 0,7$ \\
\hline III & $0,6 \pm 0,2$ & $18,2 \pm 0,9$ & $5,1 \pm 0,6$ \\
\hline IV & $3,5 \pm 0,8$ & $24,8 \pm 2,2$ & $13,0 \pm 1,5$ \\
\hline V & $3,6 \pm 0,7$ & $31,4 \pm 3,8$ & $28,0 \pm 1,9$ \\
\hline VI & $30 \pm 1,9$ & $39,4 \pm 5,7$ & \\
\hline
\end{tabular}

*average daily quantity of feed for rats- $12 \pm 4 \mathrm{~g}$

The investigation data indicate that iodinated fats influence on metabolism results leading to the accumulation of the iodine by animals, as a result of more effective digestion and assimilability of iodine from present connections.

In summary our investigations, based on estimation of iodine content in the thyroid glands of experimental animals, proved that in experimental hypothyroidism the iodine content of rats decreased from 4,8 to $1,2 \mathrm{mg} \%$ (groups I and II), and on addition of iodinated fats with iodine content ( $3 \mu \mathrm{g} / \mathrm{rat})$ the iodine quantity in thyroid gland increased from 5,4 to $13,0 \mathrm{mg} \%$ (groups III and IV).

On addition of considerable quantities of iodine $(30 \mu \mathrm{g} / \mathrm{rat})$ the iodine content also increased, but the capacity of thyroid gland for iodine accumulation is decreased (figure 5).

Analysis of iodine content in thyroid glands, which was obtained from rats after correction of iodine-critical state, at the expense of introduction in their ration of iodinated fats gives the possibility to underline the improvement of functioning and the capacity of iodine accumulation by thyroid gland.

Literature data and the results of proper research on laboratory animals lets us conclude concerning the safety, bioavailability and simplicity of use of organically connected iodine forms as iodinated fats (vegetable oil, margarine). 
Fig 5. Influence of consumption by animals of iodinated fats on the process of its metabolism and the accumulation capacity by thyroid gland.

\section{Conclusions}

1. Banding of iodine and vegetable oil gave the fixed organic connection with increased biological value, which is available for obtaining and does not require creation of additional technologies.

2. After introduction of iodinated fat products in the ration of hypothyroid animals, they manifest biological activity. Iodinated fat products contribute to restoration of such thyroid hormones levels as $\mathrm{T}_{3}, \mathrm{~T}_{4}$ and $\mathrm{TSH}$, i.e. functional activity of thyroid glands.

3. Investigational data indicate that iodinated fats influence on metabolism processes and contribute to the accumulation of the iodine by animal organism, as a result of more effective digestion and assimilability of iodine from present connections.

4. Application of iodinated fats supplies the lack of iodine in organism, does not have side effects and can be used in prevention of diseases, provoked by iodine deficiency.

\section{Experimental}

$>$ Sun flower oil fortification with iodine

In this study,doubly refined and deodorized oil was used (purchased from local stores) [STAS - 1129-93] [22].

TO OBTAIN THE IODINATED SUNFLOWER OIL, CHEMICALY PURE, CRYSTALLINE IODINE $\left(\mathrm{I}_{2}\right)$ [STAS - 4159- 79] [23] WAS ADDED. AFTER THE ESTABLISHEMENT OF THE EQUILIBRIUM, IODINATED OIL WAS USED AS SAMPLE FOR THE PRESENT STUDY.

\section{Manufacturing of iodinated margarine}

In proposed iodinated margarine, a part of sun-flower oil was replaced by iodinated doubly refined and deodorized sun-flower oil with an iodine content of $10 \mu \mathrm{g} \mathrm{I} / \mathrm{cm}^{3}$.

\section{Investigations in vivo}

For the purpose of elucidation of the influence of food regimes with different content of iodine on bioavailability of iodine from fortified lipidic products and the dynamics of evolution of experimental hypothyroidism, two series of experiments were performed.

The experiment was realized with the lot of white rats of the Wistar line with masses in the range $180-210 \mathrm{~g}$. The feed was a standard ration with free access to water. Duration of the experiment was of 42 days. The animals were kept in individual cages, 5 animals in every cage. 
The experiment had 2 stages:

Stage I - experimental reproduction of hypothyroidism with the help of mercazolile for blocking of thyroid gland function [24]. Daily (for 14 days) the rats were given water to drink with mercazole added. At the same time they were fed by bread without addition of iodinated salt (produced in the laboratory of Technical University of Moldova), with the purpose to exhaust the reserves of iodine of the organism.

Stage II - feed of animals with experimental hypothyroidism (28 days) by standard ration, without addition of iodine (group II); with additive of sunflower non-iodinated oil (group III); with addition of iodinated oil with iodine content $3 \mu \mathrm{g} /$ rat (group IV); with addition of iodinated margarine with iodine content $3 \mu \mathrm{g} / \mathrm{rat}$ (group V); with addition of iodinated oil with iodine content $30 \mu \mathrm{g} / \mathrm{rat}$ (group VI).

Scheme of experimental work with white laboratory rats is presented as Figure 6.

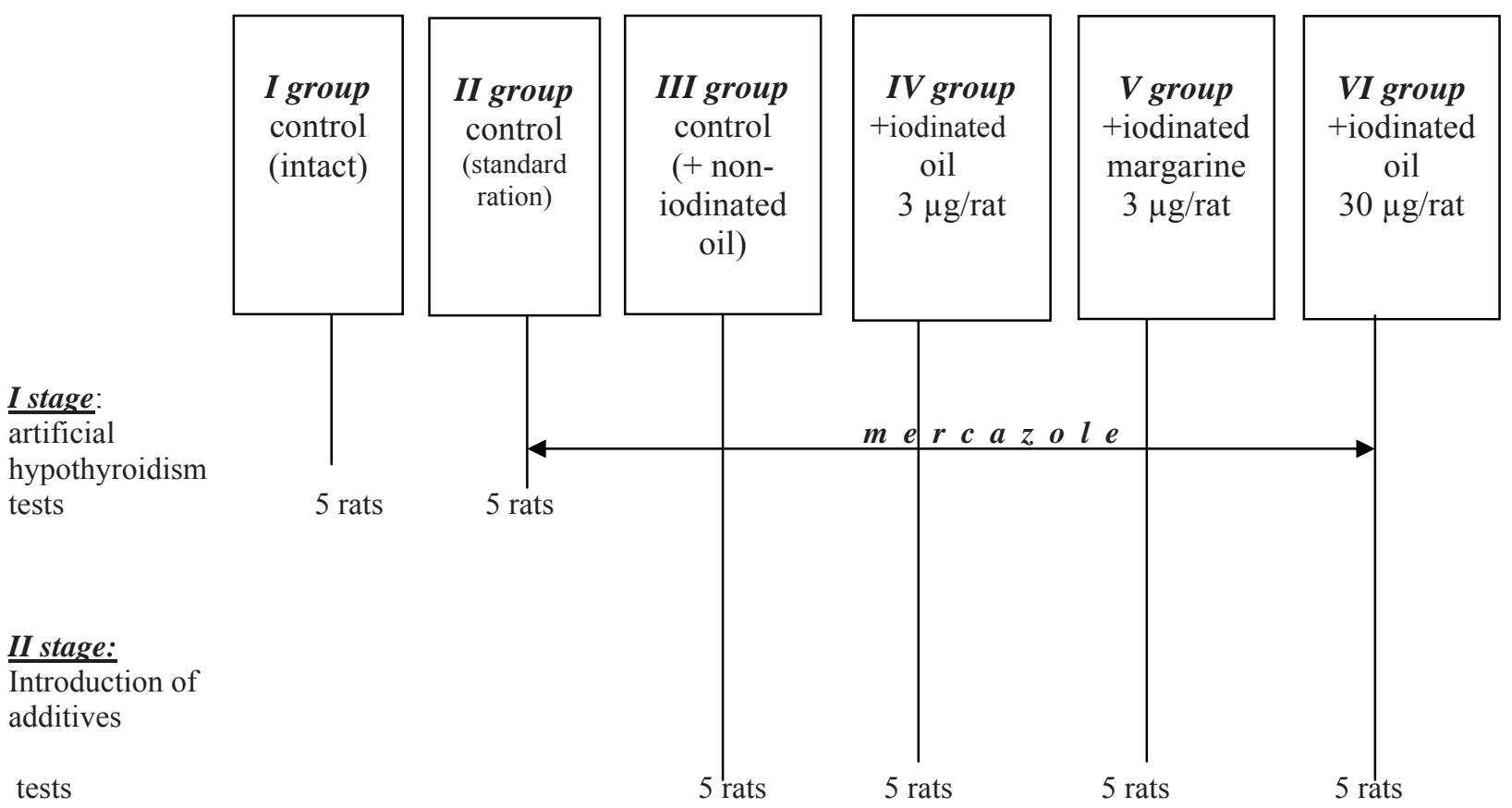

Fig 6. Scheme of experimental work with white laboratory rats

All the six groups of rats during the experiment received the following foodsuffs: whole-grain wheat porridge prepared on meat broth, so they got the lipid products. The porridge was given daily, for dinner, on the assumption of daily consumption of $12 \mathrm{~g}$ product/rat.

\section{Analysis of Total Triiodothyronine hormone $\left(T_{3}\right)$ in the serum of investigated rats}

The procedure follows the basic principle of enzyme immunoassay where there is competition between an unlabeled antigen and an enzyme-labeled antigen for a fixed number of antibody binding sites. The amount of enzymelabeled antigen bound to the antibody is inversely proportional to the concentration of the unlabeled analyte present. Unbound materials are removed by decanting and washing the wells. The absorbance measured is inversely proportional to the concentration of $\mathrm{T}_{3}$ present in the serum. A set of $\mathrm{T}_{3}$ Standards is used to plot a standard curve of absorbance versus $\mathrm{T}_{3}$ concentration from which the $\mathrm{T}_{3}$ concentrations in the unknowns was calculated.

\section{Analysis of the Thyroxine hormone $\left(T_{4}\right)$ in the serum of investigated rats}

The principle of the Thyroxine $\left(\mathrm{T}_{4}\right)$ analysis in the serum of investigated rats is the same. A set of T4 Standards is used to plot a standard curve of absorbance versus T4 concentration from which the T4 concentrations in the unknowns was calculated.

\section{$>$ Analysis of the Thyroid-stimulating hormone (TSH, thyrotropin) in the serum of investigated rats}

The TSH analysis is an enzymatically amplified "one-step" sandwich-type immunoassay. In the assay, standards, controls and unknown serum samples are incubated in microtitration wells which have been coated with anti-hTSH antibody in the presence of another anti-hTSH detection antibody labeled with the enzyme horseradish peroxidase 
(HRP). After incubation and washing, the wells are incubated with the substrate tetramethylbenzidine (TMB). An acidic stopping solution is then added and the degree of enzymatic turnover of the substrate is determined by dual wavelength absorbance measurement at 450 and $620 \mathrm{~nm}$. The absorbance measured is directly proportional to the concentration of TSH in the sample. A set of TSH standards was used to plot a standard curve of absorbance versus TSH concentration from which the TSH concentrations in the unknown samples were calculated.

\section{Analysis of iodine content in thyroid glands of investigated rats}

For analysis of iodine content in thyroid glands of investigated rats was used a spectrophotometric method of iodine determination. The Method consists in mineralization of the sample with the following extraction of iodine with carbon tetrachloride in presence of sodium nitrite in acidic medium, measurement of absorption of reaction products on wavelength $514 \mathrm{~nm}$. Relative error of average result consists $\pm 2,05 \%$ [25].

\section{$>$ Determinations of errors and statistical analysis of obtained results}

Investigations realized in triplication and processed statistically by the method of those small squares with application of coefficient Student and determination of interval of investigation [26-28].

\section{References}

[1] Delange F et. al. Risks of iodine-induced hyperthyroidism following correction of iodine deficiency by iodized salt; Thyroid, 1999; 9:545-556.

[2] Hetzel BS. Iodine deficiency disordes (IDD) and their eradication; Lancet, 1983; 2:1126-1129.

[3] Stanbury JB et al. Iodine-induced hyperthyroidism: occurrence and epidemiology; Thyroid, 1998; 8:83-100.

[4] World Health Organization, United Nations Children's Fund, and International Council for Control of Iodine Deficiency Disorders. Geneva; World Health Organization. (WHO/NUT 94.6.), 1996.

[5] Raportul UNICEF. Alimentaţia şi nutriția umană în R. Moldova. Biroul pentru Moldova. 2002; p. 38.

[6] Hotarire cu privire la aprobarea programului national de eradicare a tulburarilor prin deficit de iod pina in anul 2010. Monitorul official al RM, 1 iunie 2007.

[7] Hurrell RF. Mineral fortification of food; England: Leatherhead Food Research Association, 1999.

[8] Alioshin B.V. O necotoryh spornyh voprosah v patofiziologhii shitovidnoi jelezy.Uspehi sovremennoi biologhii. 1982; Vyp.1.s.121-138.

[9] Dedov I.I., G. A. Gerasimov, N.I. Sviridenco, A.A. Shishkina, N.M. Maiorova. Ispolizovanie tabletirovannyh preparatov ioda dlia profilactiki endemiceskogo zoba; Probl. Endokrin. 1998; Vyp.1.s.24-27.

[10] Baranov V.G., E.A. Loskutova, M.V. Pronin. O mehanizme podavlenia funkzii shitovidnoi jelezy tireoidnymi garmonami; Probl.Endokrin, 1970; Vyp.1.-s.43-46.

[11] Starcova IG. Farmacoterapia v endocrinologii; M: Medicina, 1989.

[12] Medvedev VV. Kliniceskaia laboratornaia diagnostiva; SPb: Gipocrat, 1997.

[13] Lewis G. The nature of trace element problems; delineating the field problem; Anim. Prod. Vet. Practice. Edinbergh, 1983; Vol. 7.

[14] Kashina V.K. Effektivnosti primenenia ioda v jivotnovodstve. Microelementy v biologii I ih primeneniev s.-h. I medicine;Smarkand, 1990; s.367-369.

[15] Egorov ID. Naucinye aspekty pitania ptuzy; Ptizevodstvo, 2002.

[16] Fencenko N.G. Biologiceski aktivnye veshestva v pitanii jivotnyh;Ufa, 2003;199 s.

[17] Gusacov VK. Vlianie iodosoderjashih preparatov na pokazateli krovi jivotnyh; Veterinaria, 2004; 1, 54-55.

[18] Newton GL. Iodine toxity: physiological effects of elevated dietary iodine in animals; G. Anim. Sci., 1974; Vol.39, 879.

[19] Bataev AP. Biodostupnostiioda dlia jivotnyh; Borobsc, 1991.

[20] Georgievskii BI. Mineralinoe pitanie ptizy; M: Kolos, 1970.

[21] Seliatickaia V.G. Funkcionalinoe sostoianie shitovidnoi jelezy krys, poluciavshih kolicestva ioda s pitievoi vodoi; Voprosy pitania. 1994; №9. s.50-53.

[22] STAS - 1129 - 93. Ulei de floarea soarelui. Condiții tehnice.

[23] STAS - 4159- 79. Iod Cristalin. Conditii tehnice.

[24] Teppermen D. i Teppermen H. Fiziolodhia obmena veshestv i endocrinnoi sistemy; Vvodnyi curs : Per. s angl.M.:Mir, 1989; s. 302-308.

[25] ACTES du seninaire d'animation regionale (Region Europe Centrale et Occidentale) SAR-2004 (Agence Universitaire de la Francophonie, Réseau "Génie des Procédés Qppliqué à l'Agro-Alimentare", Université Techniqué de Moldavie ; Ch.:Tehnica - Info, 2004; 380 p.

[26] Snedecor G.W. and Cochran C.V. Statistical methods Ams; IA, 1989.

[27] Lakin GF. Biometria; M.:Vysshaia shkola, 1990.

[28] Kuziahmetov GG. Metody izucenia pocvennyh vodoroslei; Ufa: Bashkirsk, 2001. 